\title{
MICHEL ONFRAY E O ATEÍSMO CONTEMPORÂNEO: CONSIDERAÇÕES E BALANÇO CRÍTICO AO TRATADO DE ATEOLOGIA
}

\author{
Abraão Lincoln Ferreira Costa ${ }^{1}$ \\ Centro Universitário Estácio de Brasília (ESTÁCIO BRASÍLIA) \\ https://orcid.org/0000-0002-2963-8943 \\ E-mail: abraaofilosofia@gmail.com
}

\section{RESUMO:}

O presente artigo apresenta aquilo que se compreende como o "ateísmo do filósofo Michel Onfray". Para tanto, desenvolve-se uma investigação baseada na obra Tratado de Ateologia a fim de balizar pontos de suas reflexões. Onfray responsabiliza os monoteísmos cristão, judaico e islâmico por introjetarem as consciências da culpa, do pecado e da pulsão da morte impedindo os homens de se reconciliarem com aquilo que entende como realidade. $O$ estudo da filosofia onfraryana ainda nos leva à tese de que a sua ontologia materialista pressupõe a inserção de um plano éticohedonista, passível de superar os obstáculos psíquicos causados pelas religiões monoteístas. Em sequência, a análise crítica tem a contribuição dos autores Irene Fernandez e Mathieu Baumier, cujo interesse é evidenciar o quanto os argumentos capazes de apontar a intolerância religiosa também podem ser motivados pelo desprezo passional à vida religiosa, afetando, consequentemente, os fundamentos dispostos a provarem ser possível existir um mundo sem deuses, crenças ou religiões.

PALAVRAS-CHAVE: Ateologia; Baumier; Fernandez; Monoteísmos; Onfray.

\section{MICHEL ONFRAY AND THE CONTEMPORARY ATHEISM: CONSIDERATIONS AND A CRITICAL BALANCE OF THE TREATY OF ATEOLOGY}

\begin{abstract}
:
This article presents what is understood as the "atheism of the French philosopher Michel Onfray". To do so, become an investigation based on the work Treaty of Ateology in order to evaluate points of its reflections. Because Onfray blames Christian, Jewish and Islamic monotheisms for introjecting the consciences of guilt, sin and the pulse of death, preventing men from reconciling with what they understand as reality. The study of onfraryan philosophy does not yet lead to the thesis that its materialist ontology presupposes the insertion of an ethical-hedonistic plan, capable of overcoming the psychological problems caused by monotheistic religions. In sequence, the critical analysis has the contribution of authors Irene Fernandez and Mathieu Baumier. The intention is to show how the arguments capable of pointing out a religious intolerance can also be motivated by the passionate contempt for religious life, consequently affecting the foundations willing to prove it possible to exist a world without gods, beliefs or religions.
\end{abstract}

KEYWORDS: Atheology; Baumier; Fernandez; Monotheisms; Onfray.

\footnotetext{
${ }^{1}$ Doutor(a) em Filosofia pela Universidade Estadual do Oeste do Paraná (UNIOESTE), Curitiba - PR, Brasil. Professor(a) do Centro Universitário Estácio Brasília (ESTÁCIO BRASÍLIA), Brasília - DF, Brasil..
}

COSTA, Abraão Lincoln Ferreira. Michel Onfray e o ateísmo contemporâneo: considerações e balanço crítico ao Tratado de ateologia. Griot : Revista de Filosofia, Amargosa - BA, v.21 n.3, p.336-350, outubro, 2021. 


\section{Introdução}

Embora não haja propriamente a formulação de ideias devidamente sistemáticas, entendemos que a filosofia de Michel Onfray desenvolve uma ontologia materialista tendo como meta a criação de uma ética hedonista. Em sentido estrito, o filósofo defende que somente negando as crenças religiosas e todo e qualquer interesse de ordem transcendente o homem pode alcançar a felicidade, pois, dessa maneira, estaria conciliado com o seu próprio corpo devido à superação da consciência da culpa dos pecados, fortemente introjetada pelas tradições monoteístas. Dando continuidade, é possível depreendermos dessa visão que as religiões transcendentes seriam, portanto, responsáveis por obstaculizar a conciliação do ser humano com o plano material. Esse impedimento, seguramente começa pela contradição entre as propostas transcendentes, defendidas pelas religiões que, segundo o filósofo, rejeitam o plano imanente responsável pela afirmação da vida.

Próximo do pensamento de Ludwig Feuerbach, para Onfray, as crenças religiosas são construções humanas, motivadas em nome da busca pelo sobrenatural, tendo em vista tornaremse acalentos do espírito humano, incapaz de encontrar na natureza todas as respostas que tanto procura (FEUERBACH, 2008, p. 55). Para o filósofo francês, é inegável que o interesse em solucionar as questões metafísicas tende a influenciar na direção da vida sociocultural de cada povo. Seu pensamento, entretanto, alerta para os riscos de tal influência causar o afastamento dos homens da realidade. Desse modo, as supostas irrealidades metafísicas denunciadas no Tratado de Ateologia trariam, em efeito, a indisposição e distanciamento junto aos interesses materiais. Logo, a certeza única que deve existir em cada indivíduo é a de possuir um corpo físico, tornando-se isto condição sine qua non para colocar em prática o projeto existencial, cuja pretensão consiste na reconciliação humana com a natureza.

$\mathrm{Na}$ intenção de destacar os principais argumentos e críticas ao Tratado de Ateologia, o artigo sintetiza os aspectos teóricos marcantes da obra e a de seus comentadores. Assim sendo, a "ateologia", termo outrora criado por George Bataille, representa a junção das diferentes áreas da ciência, envolvendo a psicologia, a psicanálise, a arqueologia, a paleografia, a história, além dos estudos que envolvem a hermenêutica, a linguística, a metafísica e a filosofia. Além de fortalecer a base argumentativa para uma vida sem deuses, crenças ou religiões, a pretensão de agrupar essas diferentes áreas do conhecimento propõe o desenvolvimento de uma teoria da imanência, disposta a sistematizar a ontologia materialista pensada pelo filósofo (ONFRAY, 2007, p. 25).

\section{A genealogia das religiões}

Na interpretação de Onfray, os monoteísmos cristão, judaico e islâmico subjugam o plano material, impondo parâmetros das coisas puras e impuras existentes no mundo. Obedecendo o entendimento de Onfray, para essas três religiões, a pureza estaria ligada ao Uno, a Deus; o Paraíso, à ideia e ao espírito, enquanto a impureza à diversidade, ao relativismo, à materialidade; o corpo, à carne, em geral, tudo àquilo de origem natural. $\mathrm{O}$ autor prossegue argumentando que algumas regras religiosas que aludem à vida cotidiana de seus fiéis discorrem sobre hábitos estritamente voltados à saúde. Certas práticas, portanto, decorreriam de exigências mais circunstanciais, por isso voltadas às necessidades básicas de sobrevivência ao invés de baseadas em qualquer motivação extra mundana. Há bons exemplos que atestam esse entendimento, vistos desde o Talmud ao Corão, responsáveis não somente por indicar várias impurezas como cadáveres, carcaças, excreções de substâncias corporais e lepra como ainda para afirmar a condição

COSTA, Abraão Lincoln Ferreira. Michel Onfray e o ateísmo contemporâneo: considerações e balanço crítico ao Tratado de ateologia. Griot : Revista de Filosofia, Amargosa - BA, v.21 n.3, p.336-350, outubro, 2021. 
ontológica de um corpo naturalmente sujeito a todas essas "imundícies", devendo assim ser rejeitado.

Dentre as diversas causas ligadas à genealogia do pecado e da impureza, Onfray (2007, p. 25) lamenta o fato de as religiões monoteístas chegarem ao ponto de acusarem as mulheres, atribuindo tais impropérios à fase de menstruação ou quando dão à luz. Assim como os cristãos, judeus e islâmicos compartilham várias concepções sobre o sentido de pureza, considerando acreditarem na impureza do corpo, mesmo não havendo explicações precisas para afirmarem muitas dessas considerações. Todavia, alguns argumentos voltados à assepsia também trazem no seu cerne a explicação do sentimento de repulsa ao próprio corpo. $O$ filósofo (2007, p. 59) sustenta que as religiões monoteístas deveriam apenas justificar suas práticas em razão da profilaxia, da higiene e da limpeza, e, no entanto, acabam fabricando outras necessidades fabulatórias. Procurando recorrer à história, Onfray diz ser possível explicar alguns desses hábitos religiosos que costumam dar início aos sentimentos de ódio e desprezo. Por que a carne de porco e não a de camelo? Para o autor, existe a hipótese do porco ser o animal emblemático de algumas legiões romanas, constituindo então más lembranças aos judeus; outra explicação estaria no caráter onívoro do animal que ingere detritos; o ódio ao cão, explicado pelo risco de suas mordidas e da transmissão da raiva; a condenação da bebida alcoólica, pelo fato de as regiões quentes parecerem propícias ao ócio, ao descanso e à busca da hidratação, sendo assim preferível a ingestão de líquidos como a água e o chá.

Salientamos que alguns hábitos religiosos parecem encontrar sentido dentro de uma motivação mais natural do que transcendente, proveniente das necessidades do corpo na intenção de preservar sobre si mesmo os cuidados que garantiriam seu bem-estar. Ações até então justificadas acabam sendo integradas ao que não possui nenhuma fundamentação. Nessa perda de bom senso, tudo se torna rígido e inflexível, pois acabam se perdendo as demais imposições morais de pouca coerência. $O$ filósofo tenta complementar essa hipótese dentro da ideia de que o corpo, ao contrair sujeiras, infecções, mau cheiro, libidinosidade, sanguinolências, morte, acaba induzindo as religiões monoteístas a adotarem uma série de proibições. Assim, a necessidade de abluções, haja vista a maior quantidade de repressões, propiciando o aumento das chances de adquirir um corpo puro e glorioso em outra vida.

É possível depreender do pensamento onfraryano que a proposta de paz e misericórdia tratada em geral nas grandes religiões monoteístas oculta o verdadeiro objetivo de sua moral: restrições à liberdade e ao prazer carnal. Esse seria o meio oferecido aos homens para ingressarem no paraíso celestial, uma vez que o devoto, recebendo a purificação, conquistaria o direito à eternidade. $O$ filósofo compreende que, da acusação do corpo como origem e desenvolvimento de todo o pecado tende a se criar uma espécie de mitificação sobre o desejo, a sexualidade, as mulheres e a ciência. Assim, as questões imanentes são colocadas em segundo plano, prejudicando toda a possibilidade de um progresso ontológico do tipo materialista.

Para Onfray, religiões como as do Cristianismo partem do problema de precisarem comprovar historicamente a existência dos seus fundadores. Sobre isso, o autor interpreta a figura de Jesus enquanto uma ideia messiânica na qual articularam-se diferentes visões de mundo acerca da realidade. Seu entendimento parte do princípio histórico de a região supostamente habitada pelos primeiros cristãos ter estado sob o domínio dos romanos, estimulando angústias e incertezas entre os judeus. $O$ remédio encontrado no interesse de solucionar as vicissitudes do povo judaico foi fabular a imagem de um Messias com o poder de libertá-los da opressão romana. Afinal, defende o filósofo, não há evidências concretas de túmulo, restos mortais, arquivos ou nenhuma outra prova científica empenhada em garantir a existência de Jesus. Diante disso, qualquer narrativa contida nos Evangelhos acabaria sendo facilmente derrubada pela ciência, como o caso

COSTA, Abraão Lincoln Ferreira. Michel Onfray e o ateísmo contemporâneo: considerações e balanço crítico ao Tratado de ateologia. Griot : Revista de Filosofia, Amargosa - BA, v.21 n.3, p.336-350, outubro, 2021. 
do tecido do Santo Sudário, já que outrora acreditavam pertencer à época de Cristo, entretanto, depois de testes realizados com o carbono 14 teria sido provada sua origem somente após o século XIII d.C. (ONFRAY, 2007, p. 97).

Motivado em buscar maiores evidências da não-existência de Jesus, Onfray desenvolve algumas justificativas empenhado em fortalecer a criação daquilo que compreende como mais uma entre tantas outras fábulas. Uma de suas primeiras investigações parte da análise do caso acontecido com Paulo de Tarso durante a sua viagem a Damasco. Na versão do pensador francês, o Apóstolo acabou sendo acometido de um grave surto psicótico, provocando a estranha alucinação do anjo e, em seguida, uma cegueira temporária. Apesar de ser apenas um mero caso de saúde mental, o poder desse episódio chegou até o imperador Constantino numa outra versão, que, somada à sua força política, acabou tornando o Cristianismo a religião oficial do Império Romano. Isto posto, seria preciso encarar a histeria de Paulo como fenômeno compreensível, provavelmente desencadeado pelo medo ou pelo stress, considerando que os judeus viviam constantemente pressionados, precisando se sujeitarem à língua oficial de Roma, além das novas leis e costumes, provocando a iminência de futuras resistências e insurreições.

A tese onfraryana tem seu complemento no argumento de que as limitações de defesa do povo judeu, diante do poder dos césares, motivou-os a única solução: inventar o artifício ideológico do "Rei dos reis", todo poderoso, capaz então de libertá-los de todo aquela opressão. Dessa análise, é correto inferir novamente um recurso antropológico proveniente da imaginação humana, a fim de que, com a esperança fictícia da personificação de um deus salvador, pudessem mitigar suas aflições, uma vez que as circunstancias, tão desfavoráveis, mostravam-se aparentemente insolucionáveis.

\section{Significados para o ateísmo}

Toda relação do homem com o mundo constitui-se de algo demasiadamente humano, conforme vimos nas explicações do filósofo francês. Onfray, portanto, considera a genealogia do ateísmo tão simples quando comparada às motivações que levam à criação das crenças religiosas. $\mathrm{O}$ ateu teria, então, sido tratado injustamente como rebelde e ignorante quanto aos supostos sinais comprobatórios da evidência do sagrado. Nesse aspecto, a história dos ateus revela um tratamento hostil, sendo por vezes considerados adoradores do diabo após negarem os preceitos vigentes pertencentes às muitas organizações religiosas. Na antiguidade, a palavra "ateu" parecia não estar qualificada e relacionada àquilo que nega a força espiritual, mas somente àquilo que recusa os deuses dominantes. Dessa maneira, o autor compreende que, no passado, o ateísmo parecia estar apenas propenso a inovar, criando então novas criaturas em seu imaginário.

Seguindo a interpretação de Onfray, na história antiga, o ateísmo conhecido de maneira subversiva veio a tornar-se um ataque não somente à religião, como também à política. Poderia então estar justificada qualquer contraofensiva de governantes e sacerdotes, através do repúdio, da excomunhão e dos ataques ferozes àqueles pertencentes a outras crenças, insubordináveis aos ditames dos deuses oficiais. Assim, o ateu se transformou numa figura insultante, destinada à blasfêmia. Somente com as tentativas de silenciamento, que variavam desde a prisão até a execução, poderiam trazer a ordem pretendida pelas organizações política e religiosa.

$O$ ateísmo carece de melhores explicações envolvendo desde então uma profunda revisão historiográfica (ONFRAY, 2007, p. 17). É preciso não confundir esse termo com o "adevismo"2,

\footnotetext{
2 Termo utilizado para negar ou reformular os deuses e a religião vigente de uma cidade ou Estado. Todavia, essa negação não implica numa descrença radical à vida espiritual, apenas a adoção de novos princípios e práticas religiosas não oficiais.
}

COSTA, Abraão Lincoln Ferreira. Michel Onfray e o ateísmo contemporâneo: considerações e balanço crítico ao Tratado de ateologia. Griot : Revista de Filosofia, Amargosa - BA, v.21 n.3, p.336-350, outubro, 2021. 
comumente visto nas ideias de alguns pensadores, a exemplo de Sócrates, Epicuro e Espinosa. Vejam que até mesmo Lutero, através do jesuíta Garasse, fôra rotulado como ateu. Tal significado extrapola a compreensão simplória da subversão e insulto aos deuses vigentes, já que propõe a negação radical de toda e qualquer espécie de força divina e transcendente. Segundo o Tratado de Ateologia, o Deus dos filósofos está em constante conflito com o Deus de Abraão, Moises e Maomé. A origem filosófica é fruto da racionalidade, enquanto o religioso exige em demasia o dogma, a revelação e a obediência. Sua inferência aponta para um Deus de aparência Iluminista, nesse caso, libertador, tendo no outro uma espécie de antítese, ao decretar em seu dogma a obediência e negação da vida.

Cabe também ressaltar a inexistência de qualquer crença do autor no deus do Iluminismo, o que o tornaria próximo do deísmo ${ }^{3}$. Em verdade, o ateísmo considera a crença iluminista de maior consistência e validez quando propõe um mundo emancipado, distante das interferências da religião cristã e do antigo regime absolutista (ONFRAY, 2007, p. 18). Contudo, ele acredita não ser possível deixar de atribuir falhas ao pensamento de alguns filósofos, a exemplo de Descartes, Kant, Rousseau e Voltaire no momento em que durante suas teses abdicaram da oportunidade de negarem toda e qualquer forma de religiosidade. Para entendermos melhor, cabe explicarmos que Onfray enxerga nos filósofos supracitados a formulação ampla e sistêmica de reflexões, apesar da mencionada negligência ou por terem sofrido as pressões sociais de seus respectivos períodos a ponto de obrigá-los a não se indisporem radicalmente com a tradição, cuja ideia de uma vida sem deuses, crenças ou religiões tornar-se-ia demasiadamente insuportável.

Deístas, sacerdotes, místicos, praticantes de variadas crenças, cada um convicto a seu modo da existência divina, sofreram perseguições, uma vez que suas formas de fé destoavam das normas estabelecidas. Isso fortalece nossa crença no tocante à crítica de Onfray a alguns filósofos iluministas, encontrando justificativa no fato de que, embora apresentassem planos filosóficos de incontestável envergadura, provavelmente estiveram impedidos de concluir autonomamente a versão da não existência divina, dada as razões de viverem sob tempos de árduas perseguições religiosas. Entretanto, o verdadeiro ateu, mesmo que vítima das terríveis perseguições, diferenciase por estar mentalmente liberto da ideia de um deus, podendo então negar facilmente a sua presença.

Mas quem de fato seria o primeiro pensador ateu? Onfray revela a versão de ter sido o padre Jean Meslier (1644-1729), que em seus livros era comum escrever contra a Igreja e Jesus. Crítico ferrenho da organização política e social do seu tempo, Meslier inaugurou uma postura negacionista acerca da crença numa força transcendente. A admiração do filósofo francês pelo sacerdote ateu consiste não simplesmente na aberta negação de qualquer religião ou metafísica, mas, sobretudo, nas condições filosóficas, as quais se apropriou para fundamentar seus argumentos. Títulos, a exemplo de Mémoire des pensées et sentiments e Des démonstrations claires et evidentes de la Vanité et de la Fauseté de toutes les Divinités et toutes les Religions du Monde, de Jean Meslier, conseguem, de acordo com Onfray, demonstrar coerência por assumirem a tarefa de justificar e provar racionalmente a não-existência divina.

Semelhante a Meslier, Holbach também se tornou outro filósofo ateu. Todavia, Onfray acusa a historiografia de ter estado sempre voltada para o Iluminismo deísta, considerando pensadores em que a temática voltava-se para as crenças religiosas e esses foram cada vez mais sendo postos à margem da história, o que tornou suas filosofias um tanto subestimadas. $\mathrm{O}$ autor prossegue considerando os contemporâneos Ludwig Feuerbach, Nietzsche e Freud decisivos na

\footnotetext{
${ }^{3}$ No dicionário Abbagnano, o verbete "Deísmo" é definido como a "doutrina de uma religião natural ou racional não fundada na relação histórica, mas na manifestação natural da divindade à razão do homem".
}

COSTA, Abraão Lincoln Ferreira. Michel Onfray e o ateísmo contemporâneo: considerações e balanço crítico ao Tratado de ateologia. Griot : Revista de Filosofia, Amargosa - BA, v.21 n.3, p.336-350, outubro, 2021. 
consolidação de um pensamento original do ateísmo, embora não possamos nos deter em justificar pormenorizadamente essas considerações em razão de que o escopo filosófico de cada um desses pensadores parece estar de certa maneira em comum acordo quando se deduz que parte de suas respectivas ideias encontra-se na afirmação de um deus ou de deuses fictícios, fabricados e projetados pelo imaginário humano.

$\mathrm{Na}$ literatura, outra reflexão extraída do refrão do escritor Fiódor Dostoiévski em $\mathrm{Os}$ irmãos Karamazov demonstra que o ódio, a morte e diversos crimes são na verdade oriundos da invocação humana à não-existência divina. Em suma, o autor russo descreve que sem a presença de Deus o homem poderia fazer tudo aquilo que bem entendesse, em virtude da ausência do pecado e das suas consequências. A tese onfraryana, no entanto, inverte a compreensão desse romance declarando que "se Deus existe, então tudo é permitido." Para tanto, Onfray tenta corroborar sua tese explicando que três milênios são suficientes para reconhecer o contrário:

Três milênios testemunham, dos primeiros textos do Velho Testamento até hoje: a afirmação de um Deus único, violento, ciumento, briguento, intolerante, belicoso gerou mais ódio, sangue, mortes, brutalidade do que paz... A fantasia judaica do povo eleito que legitima o colonialismo, a expropriação, o ódio, a animosidade entre os povos, depois a teocracia autoritária e armada; a referência cristã dos mercadores do Templo ou de um Jesus paulino que afirma vir para trazer a espada, que justifica as Cruzadas, a Inquisição, as guerras religiosas, a Noite de São Bartolomeu, as fogueiras, o Index, mas também o colonialismo planetário, os etnocídios norte-americanos, o apoio aos fascismos do século XX e a onipotência temporal do Vaticano há séculos nos menores detalhes da vida cotidiana; a reivindicação clara em quase todas as páginas do Corão de um apelo a destruir os infiéis, sua religião, sua cultura, sua civilização mas também os judeus e os cristãos em nome de um Deus misericordioso! São todas pistas para desvendar a idéia de que, justamente, por causa da existência de Deus tudo é permitido-nele, por ele, em seu nome, sem que os fiéis, nem o clero, nem o populacho, nem as altas esferas tenham o que contestar... (ONFRAY, M. Tratado de Ateologia, p. 29. Tradução: Mônica Stahel)

Mesmo com a gradual extinção de certas práticas religiosas, bem como o crescimento de maior autonomia da ética laica em relação à religião, o ateísmo pós-cristão ainda tem muito a percorrer até conquistar seu espaço de direito. Essa impressão está fundamentada na hipótese de que o abandono das práticas religiosas não tende necessariamente a desencadear o recuo da crença, o que significa que mesmo diante da perda de alguns valores sagrados - ainda que questionada a intransigência papal referente aos temas do aborto, da eutanásia ou da pesquisa com células embrionárias, muitas pessoas continuarão conservando em suas vidas alguns rituais cristãos, como batizados, casamentos e enterros.

Haveria no mundo significativa infusão ideológica, mental, conceitual e espiritual da tradição judaico-cristã, mantendo o homem culturalmente preso a ideias acerca do corpo, da alma e do espírito (ONFRAY, 2007, p. 30). Até mesmo naqueles que não professam nenhuma religião existiriam efeitos contundentes de inibição contra seus desejos e tudo aquilo que promova o prazer. Onfray menciona o direito supostamente laico enquanto exemplo de uma moralidade judaico-cristã, pois suspeita de que os fundamentos da lógica jurídica derivam das primeiras linhas do Gênese, remetendo sua compreensão a uma genealogia judaica. Assim, o aparelho, a técnica, a lógica e a metafísica existentes no direito decorrem daquilo que já fala a Bíblia.

A laicização do tribunal do júri e a proibição do uso de sinais religiosos como crucifixos e a Bíblia não são suficientemente capazes de abster a justiça da interferência de uma metafísica judaico-cristã. Essa compreensão da tese é corroborada quando o próprio autor conclui que a moral do Judaísmo e do Cristianismo legitima a responsabilidade e, por efeito, a culpa, com a punição. Seriam essas, portanto, ações ilegítimas - a responsabilidade, a culpa e a punição,

COSTA, Abraão Lincoln Ferreira. Michel Onfray e o ateísmo contemporâneo: considerações e balanço crítico ao Tratado de ateologia. Griot : Revista de Filosofia, Amargosa - BA, v.21 n.3, p.336-350, outubro, 2021. 
baseadas em crendices mágicas. A ignorância diante do pensamento pós-cristão explica a manutenção do modelo de justiça atual, sendo, todavia, necessário substituir seus critérios por aqueles que apresentem maior embasamento racional e científico. É preciso levar em conta a psicanálise freudiana e os pensadores que comprovem a força dos determinismos inconscientes, assim como questões de ordens psicológica, cultural, social, familiar e etnológica no direito. Dessa forma, acredita o filósofo, seriam fortalecidas as bases para outra visão de mundo verdadeiramente racional, desapegada do imaginário transcendente que insiste em manter os homens presos às crendices e fábulas de um mundo supra terreno.

A despeito da possível ausência de fundamentos nas considerações de o Tratado de Ateologia, é inegável seus impactos nos diferentes círculos popular e acadêmico. Cientes disso, entendemos que agora, após verificarmos o veemente ataque destinado a alguns trechos doutrinários dos três grandes monoteísmos, mostra-se necessário assegurarmos o espaço de contradição e defesa, desta vez, sob os argumentos de Irène Fernandes e de Mathieu Baumier.

\section{Considerações de Irène Fernandez}

A obra de Irène Fernandez Dieu avec esprit: réponse à Michel Onfray desenvolve o balanço crítico sobre as considerações existentes no Tratado de Ateologia. Segundo a autora, Onfray realiza aparentemente em sua obra algo próximo do que chamaríamos de "romance policial" devido ao desmedido interesse de encontrar os culpados para uma série de delitos ocorridos na história da humanidade. Para a autora, as ideias de Onfray são fruto do ódio deliberado às religiões, o que, para ela, sem dúvida, carece de revisão na medida em que o projeto de ateologia dá ênfase à singularidade a partir da desconstrução das três grandes religiões monoteístas.

A autora sustenta que as ideias do filósofo ateu provocam uma profunda violência difamatória, embasadas dentro de equívocos historiográficos e de falsos raciocínios acerca das questões teológicas. Fernandez ainda ressalta a importância de entender que, de acordo com a razão, é difícil provar tanto a existência divina quanto a sua própria inexistência. Seu interesse se resume em demonstrar que boa parte das construções argumentativas realizadas na obra de Onfay necessitam de fundamentos bem mais amplos.

\footnotetext{
Mas sabe-se o quanto é difícil provar a existência de Deus e também como é difícil provar sua inexistência. É sem dúvida a razão que conduz o autor (Onfray) ao caminho da calúnia mais do que sob a via da demonstração. Estritamente falando, e mesmo se considerássemos tudo o que se diz como palavra do evangelho (se o podemos dizer) não se poderia, para tanto, concluir a verdade do ateísmo. No mais dever-se-ia admitir que as religiões em geral e os monoteísmos em particular são uma horrível doença humana, um cancro devastador, uma calamidade sem nome, ou tudo o que se gostaria nesse gênero; mas nada impediria, intelectualmente falando e em boa lógica, de buscar à luz das ideias uma concepção mais pura da divindade. Em outras palavras, não se trata de uma questão em favor do ateísmo. Que aqueles que acreditam em Deus sejam criminosos ou estúpidos, ou mesmo os dois, não prova em nada que eles estejam errados por acreditar em Deus: talvez após tudo eles ainda não entendem nada daquele em que eles acreditam. Considerando a besteira deles, isso não teria nada de surpreendente. Mas, não se pode deduzir jamais que Deus não exista. A eventual virtude dos crentes ou a possível inteligência deles não prova que Deus exista. O problema vai além do que se diz, o que quer dizer que ele deve ser abordado de outras formas (FERNANDEZ, 2005, p. 15-16. Tradução livre). ${ }^{4}$
}

\footnotetext{
${ }^{4}$ Mais on sait que s'il est difficile de prouver l'existence de Dieu, il est tout aussi difficile de prouver son inexistence. C'est la raison sans doute qui entraîne l'auteur sur la voie de l'invective plutôt que sur celle de la démonstration. En toute rigueur en effet, et même si on prenait tout ce qu'il raconte comme parole d'évangile (si on peut dire!), on ne pourrait pas pour autant en conclu re à 
Num sentido geral, o livro Dieu avec esprit argumenta que o postulado materialistahedonista onfraryano encontra apoio no desmedido ataque às religiões monoteístas. Para Fernandez (2005, p. 17), isso simplesmente fere gravemente o princípio argumentativo que deve estar firmado na razão. Afinal, é insensato levantar uma proposta de desconstrução de qualquer tradição religiosa procedendo apenas de um pressuposto violento e comum a ela. Evidentemente, cada religião possui sua história, sendo improvável que todos os seus problemas derivam das mesmas circunstâncias, mas contrariamente, Onfray sempre as julga e as condena a partir da mesma argumentação, sem nenhuma exceção.

A autora (2005, p. 17) salienta a importância de sermos seletivos e precavidos, de modo a não incorrermos numa espécie de ódio universal contra as religiões. Ora, essas religiões registram cuidadosamente através de seus documentos aquilo que geralmente asseguram ter sido uma experiência com o divino. Daí a importância de os temas envolvendo a religiosidade nas diferentes culturas serem analisados corretamente, na espera de que com a merecida atenção certas injustiças sejam desfeitas. Segundo Fernandez (2005, p. 20), é de enorme complexidade o estudo da história antiga, sobretudo os levantamentos do Velho Testamento. Entretanto, existem acusações preciptadas quando afirmam que as religiões monoteístas incentivam a violência e a guerra, exigindo uma série de cuidados quando discutidas. Livros como Exxodo, Levítico, Deuteronômio e a Lei do Talião, afirma Fernandez (2005, p. 20-21), não estão exatamente destinados a encorajar a violência, mas sim contrariar, limitar, interditar vinganças descabidas e atos injustos praticados pelos ímpios que desconhecem as leis divinas.

Outra discussão gira em torno da pulsão da morte. Onfray acusa as religiões monoteístas de terem desenvolvido fascínio pelo fenômeno da morte - provavelmente pela grande aspiração ao além-mundo. Levando em conta esse argumento, através do Cristianismo a pulsão da morte soube empreender sobre o mundo ainda mais corrupção e decadência sobre à vida humana. Ao contrário, Fernandez (2005, p. 25) considera a acusação do filósofo prematura contra argumentando-a, no interesse de provar ser cabível perceber que em diversos momentos da história dos cristãos ocorreu a adoção de rituais conjuratórios, pretensos a espantarem a morte. Prova disso pode ser encontrada em algumas passagens bíblicas, como no Evangelho de Lucas (7: 1, 10), no momento em que Jesus cura o servo do centurião romano, ou em João (11: 1, 38), quando Jesus ressucita Lázaro. Não somente nessas passagens, como durante as celebrações cristãs, é comum identificar de maneira constante rituais que buscam a cura dos enfermos. Por esse ângulo, percebemos que a condição de vida em abundância, comumente professada pelos cristãos, envolve muito mais o comprometimento de seus fiéis de virem a realizar a tempo suas missões religiosas do que de ansiarem pela perda de suas vidas.

Fernandez prossegue com as críticas a Onfray, também por invocar na sua filosofia o argumento psicanalítico, como se tratasse de uma verdade primeira e cientificamente comprovada. Com base nisso, a autora afirma: "ele (Onfray) parece acreditar que a psicanálise é uma ciência da mesma ordem que a genética ou que a física. Ora, trata-se de uma disciplina 
fascinante e do mais alto interesse para o conhecimento da alma humana, mas ela não tem nada de uma ciência exata" (FERNANDEZ, 2005, p. 27. Tradução livre) ${ }^{5}$

A autora ainda aponta o tema da pulsão da morte para a existência de controvérsias durante o estudo da psicanálise. Isso significa que nem todos os estudiosos parecem concordar, haja vista as diferentes hipóteses surgidas em torno dessa pesquisa. Fernandez conclui que sempre existiram dificuldades para estabelecer teorizações coerentes dentro dos estudos da psicanálise. Freud, por exemplo, compreende que as pulsões humanas seriam analogamente seres místicos grandiosos e indeterminados - logo, não é tão simples explorar a mente humana. $O$ caráter subjetivo, bastante defendido no pensamento onfraryano, também é o mesmo que poderia conduzir o ser humano a diferentes interpretações, o que prova para a autora tornar-se absurdo proporem-se explicações dessa ordem de modo tão superficial. Afinal, existiria, no Tratado de Ateologia, afirmações mais recentes do que demonstrações que pretendam justificar de modo claro os argumentos que giram em torno da afirmação de uma adoração à morte.

Outro argumento intrigante levantado pela autora refere-se ao ódio à inteligência. $\mathrm{Na}$ explicação de Fernandez (2005, p. 45), o filósofo francês entende as religiões como responsáveis pelo desencadeamento do desprezo à liberdade, ao saber e à vida científica, decretando assim a decadência da civilização ocidental. No entanto, Fernandez considera que esses argumentos antirreligiosos estariam repletos de generalizações e conclusões absurdas, pois, para ela, é preciso entender que a compreensão de ciência apresentada no cristianismo de Paulo não tem nenhuma correspondência com o que nasceu na modernidade. Lembrar que a noção do termo foi inaugurada no século XVII, faz com que seja desmontada completamente qualquer tipo de interpretação em que a coloque como um conhecimento censurado pela Bíblia. Outro apontamento levantado faz referência às diferentes informações existentes nos livros de Gênesis e de Coríntios, dificultando mais ainda a tarefa de relacionar os assuntos contidos nas escrituras.

A leitura exegética feita no Gênesis, tanto pelos judeus e cristãos, quanto por estudiosos ateus, corrobora um texto célebre, com teor complexo, repleto de informações de nível moral e existencial (FERNANDEZ, 2005, P. 46). Por outro lado, a gnosis de Paulo em nada encontra semelhança com o conhecimento racional e abstrato o qual Onfray diz que o apóstolo condena. Trata-se de revelações muito dispostas em anunciar os dons do Espírito Santo e os procedimentos religiosos que devem ser adotados por aqueles que buscam adquiri-los.

Em síntese, a autora (2005, p. 49) defende que Onfray apresenta uma tese menos racional do que a dos próprios textos bíblicos por ele condenados. O filósofo destina uma fúria a Paulo de Tarso, ao que tudo indica não conhecer limites. As acusações feitas ao apóstolo de um comportamento histérico e misógeno, com repulsa à sexualidade, devido a uma impotência, bem como a limitação intelectual, permitindo-o apenas ludibriar as pessoas mais simples de sua época, tornam, de acordo com a escritora, as considerações de Onfray "francamente falsas". Fernandez ressalta, no mais, que Paulo não foi o fundador do Cristianismo, sendo essa uma hipótese gratuita, fortemente contestável de acordo com sérias correntes historiográficas. Assim sendo, novamente se torna indispensável reforçar a seriedade a ser perscrutada durante a exposição de uma tese. Para tanto, veremos agora novas considerações feitas pelo escritor e crítico literário Matthieu Baumier.

\footnotetext{
${ }^{5}$ Il a d'ailleurs l'air de croire que la psychanalyse est une science du même ordre que la génétique ou que la physique. Or s'il s'agit d'une discipline fascinante et du plus haut intérêt pour la connaissance du coeur humain, elle n'a rien d'une science exacte.
}

COSTA, Abraão Lincoln Ferreira. Michel Onfray e o ateísmo contemporâneo: considerações e balanço crítico ao Tratado de ateologia. Griot : Revista de Filosofia, Amargosa - BA, v.21 n.3, p.336-350, outubro, 2021. 


\title{
O antitratado de Matthieu Baumier
}

Seguindo a mesma direção de Irène Fernandez, Matthieu Baumier, em L'anti Traité d'athéologie: le système Onfray mis à nu sustenta a importância da harmonia entre ciência e religião. Reutilizando antigas declarações do papa João Paulo II, Baumier afirma que o pontífice, sendo a principal voz da Igreja Católica, considerava o conhecimento científico como possuidor de grande consciência acerca do mundo e do homem. Conforme Baumier, mesmo que essa consciência apresente uma compreensão dessa realidade de maneira finita, deve sempre haver o esforço para que a religião assuma a responsabilidade em explorar as questões que dão acesso ao mistério:

\begin{abstract}
Eu não posso mais deixar, enfim, de me voltar na direção dos cientistas, que em suas pesquisas nos trazem um conhecimento crescente do universo junto com a diversidade, incrivelmente rica de suas composições animadas e inanimadas, com suas estruturas atômicas e moleculares complexas. Sobre o caminho percorrido, especialmente nesse século, eles ultrapassam etapas que não cessam de nos impressionar. Exprimindo minha admiração e meus encorajamentos aos valores pioneiros da pesquisa científica, aquelas a que a humanidade deve uma tão grande parte de seu desenvolvimento atual, sinto o dever de os exortar a prosseguir seus esforços em estabelecer sempre dentro de uma perspectiva sapiencial, nas quais os avanços cientificos e tecnológicos se associam aos valores psicológicos e éticos que são manifestações específicas e essenciais da pessoa humana (JOÃO PAULO II, Apud BAUMIER, 2005, p. 96. Tradução livre). ${ }^{6}$
\end{abstract}

Assim, para Baumier, fundamentalistas cristãos consideram a Bíblia como uma obra detentora da verdade que está acima da ciência. Diferente dessa convicção, fundamentalistas ateus, cientistas e materialistas entendem que a própria ciência em seu caráter imanente anula toda percepção sagrada do mundo. Existem, portanto, dois grupos extremistas disputando uma verdade absoluta. Segundo o autor, trata-se de um confronto tolo e maniqueísta, do qual Onfray é um de seus adeptos. O que leva a filosofia onfraryana a fazer parte de um desses discursos extremistas é sua profissão de fé no materialismo, acreditando que haja nisso coerência e capacidade de envolver toda a realidade.

Baumier ressalta a importância de contestar a luta entre os diferentes tipos de fundamentalismos religiosos e materialistas que se apresentam, já que estes em sua radicalidade tornam-se incapazes de responder qualquer coisa sobre a realidade. A noção de totalidade defendida por qualquer ideologia torna-se perigosa. Aparentemente, dentro de um tom mais conciliatório, o autor $(2005$, p. 100) sustenta que ciência e religião devem comparar seus métodos e também seus modos de trabalho. As convergências, declara Baumier, servem de base para o enriquecimento de ambos os saberes, permitindo que juntas caminhem em direção à certeza do real. A combinação entre ciência e religião é o resultado de uma parceria voluntária e sistemática. $O$ interesse maior é favorecer a integração entre os dois domínios de pesquisa. Dessa maneira, pensa Baumier, não existiria nenhum problema em perceber que durante os avanços da astronomia, da física e da química fosse mantido o comprometimento de uma abordagem teológica, no interesse de contribuir para a solução de questões que estivessem acima da razão.

\footnotetext{
${ }^{6}$ Je ne peux manquer non plus, enfin, de me tourner vers les scientifiques qui, par leurs recherches, nous apportent une conaissance croissante de l'Univers dans son ensemble et de la diversité incroyablement riche de ses composantes animées et inanimées, avec leurs structures atomiques et moléculaires complexes. Sur le chemin parcouru, spécialement en ce siècle, ils ont franchi des étapes qui ne cessant de nous impressionner. En exprimant mon admiration et mes encouragements aux valeureux pionniers de la recherche scientifique, auxquels l'humanité doit une si grande part de son développement actuel, je ressens le devoir de les exhorter à poursuivre leurs efforts en demeurant toujours dans une perspective sapientielle, dans laquelle les acquis scientifi et technologiques s'associent aux valeurs philosophiques et éthiques qui sont des manifestations spécifiques et essentielles de la personne humaine.
}

COSTA, Abraão Lincoln Ferreira. Michel Onfray e o ateísmo contemporâneo: considerações e balanço crítico ao Tratado de ateologia. Griot : Revista de Filosofia, Amargosa - BA, v.21 n.3, p.336-350, outubro, 2021. 
Sua compreensão parte de que todas as teorias científicas comportam em si mesmas um princípio de incerteza. Tal tese é corroborada na medida em que compartilha da mesma ideia de Heisenberg e do teorema de Godel. Logo, a incerteza da religião em assuntos imanentes poderia dispor do precioso auxílio da ciência, bem como os conteúdos científicos em razão de suas limitações naturais obteriam ajuda das interpretações religiosas. $O$ autor complementa haver no materialismo de Michel Onfray uma "propaganda antimonoteísta", acarretando contra sua própria concepção filosófica uma postura totalitária e agressiva. Ele alega que a Igreja é regularmente acusada de obscurantismo por não compartilhar da mesma ética defendida pelos simpatizantes de alguns avanços científicos, como os do aborto ou do uso de contraceptivos. Isso teria ocasionado um crescente rechaço à posição do Vaticano, não dando ao mesmo sequer a condição de expor mais abertamente suas justificações. Nesse sentido, cabe cada vez mais o uso correto da democracia, permitindo sempre a liberdade de expressão a cada cidadão, sem que nenhum argumento seja exposto ao ridículo.

O Antitratado conclui acerca do homem a sua própria complexidade, tornando-o difícil de ser definido, conforme as pretensões de qualquer plano de imanência. O materialismo, ao combater a metafísica tradicional, assume uma postura ideologizante, comportando-se semelhante a outras ideologias possuidoras de pretensões revolucionárias. Comum ao entendimento de Irène Fernandez, Baumier certamente identifica uma incoerência na proposta subjetivista de Michel Onfray, uma vez que busca valorizar em sua tese a singularidade. Não pode haver qualquer respeito à singularidade quando as ideias onfraryanas parecem trazer de maneira tão radical a necessidade do extermínio a todo e qualquer pensamento no rumo da transcendência.

O materialismo hedonista traz consigo uma espécie de luta pelo poder. As afirmações de que a matéria é a realidade fundamental do universo possuem certa intransigência. O materialismo, conforme explica Baumier, busca restituir a constituição do real, perdida pelas imposições de uma tradição judaico cristã. Para ele, essa ideologia de caráter imanente define seus métodos de compreensão da realidade, acreditando que os fenômenos só podem ser explicados pelas ações de seus componentes materiais.

Ciência e religião são dois domínios distintos, entretanto interativos. Ambos os domínios expressam campos diferentes, mas que também podem apresentar pontos semelhantes. Baumier acusa Onfray de colocar a religião em constante conflito com a ciência. Ele ressalta que a ciência medieval, diferente daquilo que o Tratado de Ateologia coloca, foi de inestimável contribuição para o surgimento da ciência moderna. Ora, o que seria da modernidade sem o proveito das ideias de Robert Grosseteste, Roger Bacon e Albert Le Grand? Segundo o autor (2005, p. 105), Bacon já afirmava que somente com a razão nada poderia ser provado, evidenciando com isso a importância da experiência em relação à pesquisa.

Durante a ciência medieval já se praticava o método de pesquisa ordenada, passando da análise para a síntese, além da conquista de importantes áreas de estudo como a óptica, a mecânica dos corpos e o estudo dos planetas e dos animais. Para o autor, isso demonstra considerável equívoco no conflito desencadeado por Onfray entre ciência e religião. A tese onfraryana entende que os avanços da ciência dependem de um total desprendimento da cultura religiosa, enquanto Baumier contra-argumenta em seu livro, apresentando a necessidade do auxílio da religiosidade, na intenção de socorrer a ciência diante de temas mais misteriosos, portanto, inacessíveis à razão.

Baumier complementa declarando que, atualmente, a religião busca uma aproximação com a ciência, através do diálogo e da integração de suas propostas. No entanto, reconhece que essa discussão não parece ser nada fácil, na medida em que temas polêmicos, conforme os apresentados na bioética, parecem ir de encontro à violação dos principais princípios defendidos

COSTA, Abraão Lincoln Ferreira. Michel Onfray e o ateísmo contemporâneo: considerações e balanço crítico ao Tratado de ateologia. Griot : Revista de Filosofia, Amargosa - BA, v.21 n.3, p.336-350, outubro, 2021. 
pelas religiões monoteístas. Contudo, temas específicos, em astronomia, evolução, genética, biologia e física podem conquistar cada vez mais proximidade com o saber religioso. $O$ exemplo claro disso, lembra Baumier, é a física quântica, que nos últimos tempos conseguiu transformarse num importante avanço no diálogo entre as noções da imanência e da transcendência.

Baumier (2005, p. 111) considera que a prova histórica de que Jesus existiu é outro ponto que carece de maior entendimento no Tratado de Ateologia. É preciso não somente admitir a realidade teológica da encarnação e da ressurreição de Cristo, como também verificar a existência de provas fundamentais da sua existência na história. Sua tese compreende como fundamental e irrevogável essa exposição, devido aos constantes avanços da ciência e da razão. Nesse sentido, a pesquisa sobre a prova da existência histórica de Jesus torna-se fundamental no presente. Pode haver sustentação da existência de Jesus nos dois sentidos, mesmo que a prova esteja apenas concentrada no coração daqueles que acreditam. Logo, independente das provas históricas, há que se entender a importância dessa aceitação como ato único de fé. $O$ autor presume estar consciente de que essa proposta não garante nenhum tipo de prova sobre a existência de um Messias, entretanto procura mostrar que os resultados dessa pesquisa seria algo contingente para aqueles que se valem apenas da fé para aceitarem os seus ensinamentos.

Existe uma distinção entre o Jesus histórico e o Jesus real para os cristãos (2005, p. 112). $O$ anti tratado de Baumier considera essa separação relevante, a partir de duas razões. A primeira: Jesus, independente das provas históricas ao se tornar um personagem real através da fé, que tem sido disseminada ao longo dos tempos. $\mathrm{O}$ autor acredita que dificilmente algum crente equivaleria o Jesus da sua fé à figura de um homem histórico, mesmo acreditando na importância de se conquistar a prova da sua existência na história. A segunda razão apontada se deve à origem científica: os feitos de um homem vivendo e pregando em um momento preciso da história estariam contidos numa forma de estudo, cujos métodos da ciência histórica distinguiam-se consideravelmente da figura do Messias vislumbrada pelos seus fiéis.

É possível entender que a necessidade dessa distinção entre um Jesus da fé para um Jesus da ciência se deve à ausência do olhar transcendente, quando analisado unicamente pela razão. Ao que parece, a solução encontrada no intuito de desmerecer o argumento de Onfray está na confirmação de estudos que afirmam já existir fortes indícios que podem em pouco tempo comprovar a existência histórica de Jesus. Exemplo disso é a obra de John P. Meier, Un certain juif, Jésus. Para Baumier, se trata de uma referência para o conhecimento histórico da vida do Messias. O desenvolvimento da proposta de distinção dos dois tipos de Jesus foi idealizado com base nas pesquisas de Meier. Ambos veem como necessária a separação entre história e religiosidade no intuito de proporcionar uma melhor análise dessas leituras. Não se trata, para os autores, de diferentes homens, porém, comenta Baumier, a pesquisa histórica relativa à vida de Jesus poderia colidir com elementos da parte religiosa, gerando possíveis constrangimentos e interferências na produção científica.

Baumier (2005, p. 114) afirma que a tese concluída da pesquisa, acrescida do respaldo de grande parte da comunidade histórica, é que de fato existiu um Jesus de Nazaré. A má notícia, relata o autor, é que somente foi possível conhecer parte da sua história, principalmente os últimos anos da sua vida. Ele argumenta haver sério interesse da Igreja Católica nas pesquisas sobre a vida histórica de Jesus. Com base nisso, apresenta outra crítica ao Tratado de Ateologia, tendo como motivo a obra considerar que Cristo seria um personagem conceitual, construído de acordo com os interesses ideológicos da época. A acusação de que o Catolicismo teria sido em boa parte responsável pela difusão ideológica dessa ficção contraria, de acordo com Baumier, a correta postura da Igreja, pois a mesma, nos últimos tempos, tem se mantido como grande colaboradora da ciência, no interesse da obtenção de maiores dados sobre a vida do Messias.

COSTA, Abraão Lincoln Ferreira. Michel Onfray e o ateísmo contemporâneo: considerações e balanço crítico ao Tratado de ateologia. Griot : Revista de Filosofia, Amargosa - BA, v.21 n.3, p.336-350, outubro, 2021. 
Certamente, as informações histórico-científicas do homem Jesus são poucas. Na obra de Meier, descreve Baumier (2005, p. 114), relata-se a existência de um personagem considerado como um "judeu marginal", vivendo numa província marginal, com ideias também marginais. Tudo isso acontecia dentro de uma região anexada ao Império Romano - inferindo-se dessa compreensão o provável indício do descompromisso histórico de Roma no que tange aos relatos históricos da época e dessa região. Não é possível acreditar que a figura de Cristo tenha gerado considerável repercussão em sua fase inicial, já que, historicamente, deduz-se que a razão disso se devia tanto ao desprezo dos romanos quanto da própria tradição judaica da época.

Na história, existem diversos assuntos de difícil entendimento por conta da precariedade das fontes de pesquisa - a antiguidade é prova contundente disso. Baumier comenta o porquê de tantas indagações acerca da veracidade histórica de Jesus, quando existem indícios menores da vida de outros célebres personagens da história antiga. A perseguição histórica é menos intensa para com antigos conquistadores como Alexandre "o Grande", faraós ou homens como Sócrates cuja existência até o momento nunca foi categoricamente provada, mesmo assim sustentada sem a menor dúvida pelo filósofo ateu. $\mathrm{O}$ autor acrescenta citando exemplos de imperadores romanos, após Jesus, dos quais a história desconhece a data de nascimento e da morte.

\begin{abstract}
Nossos conhecimentos relativos ao fim da vida de Jesus são numerosos, muito mais numerosos que conhecimentos relativos aos homens da Antiguidade dos quais ninguém pensaria em colocar a existência em dúvida. Assim, conhecemos o essencial da cronologia do fim da vida desse homem enquanto ignoramos aquela de vários reis antigos ou de grandes homens (Sócrates por exemplo). Há mesmo imperadores que não sabemos a data de nascimento nem a data das suas mortes. Alexandre o Grande? Nossos conhecimentos precisos de sua biografia são fracos, e resumem-se a duas ou três folhas datilografadas. $O$ que dizer dos reis da Babilônia ou dos faraós egípcios de quem conhecemos somente o nome, enquanto a importância deles, no tempo deles, era extraordinária. Isso acontece com a história antiga: o conhecimento histórico desse período da humanidade é obviamente advindo dos conhecimentos que levam os historiadores a encontrarem as maiores dificuldades. Não se pode esperar conhecer os feitos do que foi vivido por um homem da Antiguidade tão bem quanto os feitos de homens mais próximos a nós. A figura de Jesus se sobressai devido ao fato de que conhecemos a seu respeito mais coisas do que sobre muitos imperadores romanos. ${ }^{7}$
\end{abstract}

A história antiga possui uma riquíssima fonte de conhecimentos, apesar de pouco explorados. É certo admitir que não se pode exigir a obtenção de conhecimentos tão amplos sobre a vida e a história de homens que viveram na antiguidade, semelhante a de figuras históricas contemporâneas. Com isso, acreditamos que as reflexões apresentadas por Baumier reiteram a importância dos requeridos cuidados no decorrer das análises feitas através da história e de outras ciências, mantendo-as ao máximo desprovidas de qualquer espécie de motivação pessoal, caso venha, consequentemente, atrapalhar a legitimidade da toda pesquisa.

\footnotetext{
${ }^{7}$ Nos connaissances relatives à la fin de la vie de Jésus sont nombreuses, beaucoup plus nombreuses que bien des connaissances relatives à des hommes de l'Antiquité dont personne ne songerait à mettre l'existence em doute. Ainsi, nous connaissons l'essentiel de la chronologie de la fin de la vie de cet homme tandis que nous ignorons celle de nombreux rois antiques, ou de grands hommes (Socrate par exemple). Il est même des empereurs romains dont nous ne connaissons ni la date de naissance ni celle de leur mort. Alexandre le Grand? Nos connaissances précises de sa biographie sont très faibles, elles se résument à deux ou trois feuillets dactylographiés. Que dire de rois de Babylone ou de pharaons égyptiens dont nous ne connaissons que le nom tandis que leur importance, em leur temps, était prodigieuse? Il en va ainsi avec l'histoire antique: la connaissance historique de cette période de l'humanité est évidemment de celles qui amènent les historiens à rencontrer le plus difficultés. L'on ne peut espérer connaittre le vécu d'um homme de de l'Antiquité aussi bien que celui d'hommes plus proches de nous. La figure de Jésus se distingue par le fait que nous connaissons à son propos plus de choses qu'à celui de bien des empereurs romains (BAUMIER, M. L'anti traité d'athéologie: le système Onfray mis à nu. p, 115 et 116. Tradução livre).
}

COSTA, Abraão Lincoln Ferreira. Michel Onfray e o ateísmo contemporâneo: considerações e balanço crítico ao Tratado de ateologia. Griot : Revista de Filosofia, Amargosa - BA, v.21 n.3, p.336-350, outubro, 2021. 


\section{Considerações finais}

Apesar da performance estilística temos a forte impressão de que o ateísmo de Onfray se nutre, aparentemente, da mesma passionalidade quando comparado a alguns preceitos religiosos dos quais ele próprio critica. Ora, se o caráter antropológico fuerbachiano explica a relação entre o homem e as crenças supraterrenas como parte essencial da sua natureza, então deduzimos ser um tanto prematura a esperança de qualquer afastamento do homem das metas transcendentes. Se, por um lado, Onfray entende a utilidade de estudos como a história e a arqueologia como componentes suficientes para alicerçarem o seu Tratado de Ateologia, por outro, vale destacar que esses estudos também verificam registros da espécie humana em que há bastante tempo é notado o interesse dos homens pelo sagrado. Formas comportamentais já encontradas há milhares de anos em antigos povos demonstra a concepção de algo transcendente, indicando interesses bem além das exigências imediatas de sobrevivência e da reprodução biológica.

Vimos nas críticas de Irene Fernandez e de Mathieu Baumier argumentos de encontro às considerações onfraryanas, contudo é preciso reconhecer a força da tese do filósofo francês a respeito das influências geográficas e sociológicas e o quanto demarcam a ideia de uma pecaminosidade intimamente relacionada às questões comportamentais educadoras como a higiene e a sobrevivência em grupo. É salutar a hipótese de que muitas considerações religiosas acerca do corpo físico partem de motivações provenientes do tempo, do clima e do lugar. Em suma, as condições de sobrevivência instigam os seres humanos a realizarem certas projeções, por vezes divinizando e condenando coisas pertencentes ao ambiente ao qual estejam submetidas. No entanto, apesar do auxílio das ciências se mostrar inegável para o entendimento das condições de sobrevivência dos diferentes povos é mister nos atermos ao nível de profundidade das explicações religiosas que, de costume, ultrapassam quaisquer preceitos de ordem geográfica, histórica ou antropológica. Vemos, portanto, tratar-se de algo precipitado a visão genérica de que todos os ritos e dogmas religiosos circunscrevem as condições de sobrevivência, ignorando, desse modo, o valor do mistério e as contribuições de sabedorias contidas nos diferentes preceitos integrados nas diversas culturas religiosas.

As motivações que levaram à criação do Tratado de Ateologia resultam muito mais no desencanto da vida religiosa do que no mais bem elaborado plano lógico-argumentativo disposto a provar a inexistência do divino. O envolvimento de Onfray, a ponto de torná-lo parcial em desmerecer os monoteísmos, provavelmente tenha em boa medida comprometido aquilo que de essencial deve existir em qualquer pesquisa filosófico-científica, isto é, o distanciamento concernente ao objeto de estudo. Não obstante, estaríamos sendo injustos com o filósofo caso atribuíssemos à sua obra um escopo de pretensão exclusivamente acadêmica, embora isso não o desobrigue dos passos necessários que garantam os fundamentos e a credibilidade dos seus argumentos. 


\section{Referências}

ABBagnanO, Nicola. Dicionário de Filosofia, verbete: “Deísmo". São Paulo: Martins Fontes, 2000.

BAUMIER, Matthieu. L'anti traité d'athéologie: Le système Onfray mis à nu. Paris: Presses De La Renaissance, 2005.

FERNANDEZ, Irène. Dieu avec esprit: Réponse à Michel Onfray. Paris: Éditions Philippe Rey, 2005.

FEUERBACH, Ludwig. La esencia de la religión. 2 ed. Trad.: Tomás Cuadrado. Madrid: Páginas de Espuma, 2008.

MATA, João. Prazer e Rebeldia: O Materialismo Hedonista de Michel Onfray. Rio de Janeiro: editora Achiamé, 2007.

ONFRAY, M. Tratado de Ateologia: física da metafísica. Trad.: Mônica Stahel. São Paulo: Martins Fontes, 2007, p. 25.

ONFRAY, M. L'art de jouir: pour un matérialisme hédoniste. Paris: Grasset, 1991.

Autor(a) para correspondência / Corresponding author: Abraão Lincoln Ferreira Costa. abraaofilosofia@gmail.com 